\title{
N-Terminal Amino Acid Sequences of Neutral Proteases from Bacillus amyloliquefaciens and Bacillus subtilis: Identification of a Neutral Protease Gene Cloned in Bacillus subtilis
}

\author{
Kazuaki Manabe, Mitsuyoshi Morit, Masaru Honjo, Masaharu OHoKa, \\ Kouichiro Fushimi, Akiko Sawakura and Yoshio Furutani \\ Biotechnology Laboratory, Central Research Institute, Mitsui Toatsu Chemicals, Inc., \\ 1900 Togo, Mobara, Chiba 297, Japan
}

Received October 1, 1984

\begin{abstract}
Bacillus subtilis 1A20 transformed with a hybrid plasmid, pNP150, to which a DNA fragment from Bacillus amyloliquefaciens $\mathrm{F}$ was attached, produced a large amount of a neutral protease. To identify the origin of the gene specifying this neutral protease, neutral proteases from $B$. amyloliquefaciens F, B. subtilis NP58 (a derivative of Marburg 6160), and B. subtilis 1A20 transformed with pNP150 were purified. We investigated their immunological properties and primary structures.

The proteases from these two species were indistinguishable by chromatography, but they were distinguishable from each other by SDS-polyacrylamide gel electrophoresis and double immunodiffusion. Amino acid sequencing of these two proteases by Edman degradation showed that there were four substitutions in the 20 -residue amino acid sequence from the $\mathrm{N}$-termini.

Neutral protease from the transformant had the same immunological characteristics and $\mathrm{N}$ terminal amino acid sequence as that from $B$. amyloliquefaciens. These results meant that the gene in question was derived from a gene specifying the neutral protease in this bacterium.
\end{abstract}

Bacillus subtilis has valuable characteristics such as secreting proteins into its culture medium and lacking pathogenicity, so it may be usable as a secretory vector system in industrial production. To construct, using recombinant DNA techniques, an efficient secretory vector system, a gene with a strong promoter and an effective leader sequence is needed. Since the production of a neutral protease by Bacillus amyloliquefaciens reaches 3 to $5 \mathrm{~g} /$ liter, the gene specifying this protease is probably suitable.

Recently we constructed a hybrid plasmid, pNP150, possessing a fragment of the DNA of B. amyloliquefaciens. ${ }^{1)}$ B. subtilis $1 \mathrm{~A} 20$ transformed with this plasmid produces a large amount of a neutral protease. We tried to compare this protease with that of B. amyloliquefaciens, but failed. The only information available for this task was the report by Levy et $a .^{2)}$ on the $\mathrm{N}$-terminal amino acid sequence of the neutral protease from $B$. subtilis NRRLB3411.

Here, we purified the neutral proteases produced by $B$. amyloliquefaciens and B. subtilis, and investigated their immunological crossreactivity, their mobility in SDS-polyacrylamide gel, and their $\mathrm{N}$-terminal amino acid sequence. We also purified the neutral protease produced by the transformant carrying the plasmid pNP150, and compared it with those of the parental strains.

\section{MATERIALS AND METHODS}

Microorganisms. B. amyloliquefaciens F (ATCC 23350), the kind gift of Dr. K. Yamane, was used as the DNA donor strain; it produces a large amount of a neutral protease. B. subtilis 1A289 was used as the host for cloning of the neutral protease gene. B. subtilis $1 \mathrm{~A} 20$ was used as another host for this gene after its insertion into the 1A289 strain. B. subtilis 1A289 and 1A20, which produce little neutral protease, were obtained from the Bacillus Genetic 
Stock Center of Ohio State University. B. subtilis NP58, ${ }^{3}$ a strain that produces abundant neutral protease, which was constructed by DNA-mediated transformation from B. subtilis IAM1212 to B. subtilis M6160, was used in the purification of the neutral protease of this species.

Isolation of a transformant producing much neutral protease. Details about the isolation of a transformant are given elsewhere. ${ }^{1)}$ In brief, chromosomal DNA from $B$. amyloliquefaciens was isolated and partially digested with the restriction endonuclease Sau3AI. After isolation of 2to 9-kb fragments, they were ligated onto the BamHI site of plasmid pUB110. B. subtilis $1 \mathrm{~A} 289$ was transformed with ligation mixture using the method of Chang and Cohen. ${ }^{4)}$ Transformants resistant to kanamycin were transferred onto casein-kanamycin plates to check for halo formation. Of the some 100,000 transformants tested, one transformant formed a large halo. This transformant harbored a hybrid plasmid that we named pNP150. B. subtilis 1A20 was transformed with pNP150 as described by Saito et al. ${ }^{5)}$; the strain stably maintained the recombinant plasmid. All kanamycin-resistant transformants formed large halos. One of these transformants (B. subtilis 1A20-pNP150) was used in the enzyme purification.

Culture of microorganism. B. amyloliquefaciens $\mathrm{F}$ and $B$. subtilis NP58 were grown in a medium of soybean cake extract and dextrin supplemented with $0.2 \%$ yeast extract. This medium is used in the industrial production of Bacillus enzymes (Dr. Tsuru, personal communication). Our medium contained $60 \mathrm{ml}$ of soybean cake extract (filtrate of the extract of a 150 -g soybean cake with one liter of hot $0.5 \mathrm{~N} \mathrm{NaOH}$ ), $13 \mathrm{~g}$ of $\mathrm{KH}_{2} \mathrm{PO}_{4}, 8 \mathrm{~g}$ of dextrin, $0.3 \mathrm{~g}$ of $\mathrm{MgSO}_{4} \cdot 7 \mathrm{H}_{2} \mathrm{O}, 0.5 \mathrm{~g}$ of $\mathrm{KCl}, 0.2 \mathrm{~g}$ of $\mathrm{CaCl}_{2}$, and tap water in one liter ( $\mathrm{pH} 7.2$ before sterilization). $B$. subtilis 1A20-pNP150 was grown in BY medium ${ }^{6)}$ supplemented with $5 \mu \mathrm{g} / \mathrm{ml}$ kanamycin. Culture supernatants were obtained by centrifugation of the culture broth.

Purification of neutral protease. Neutral proteases from B. amyloliquefaciens and B. subtilis NP58 were purified as described below. All of the procedures were at $0 \sim 4 \mathrm{C}$ unless otherwise indicated.

Step 1. Ammonium sulfate precipitation.

The culture supernatant was brought to $75 \%$ saturation with ammonium sulfate, left overnight, and centrifuged; the precipitate was suspended in one-fifth volume of the

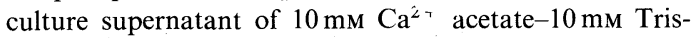
$\mathrm{HCl}$ buffer (TCa buffer), pH 7.2. This suspension was dialyzed against $\mathrm{TCa}$ buffer, and the precipitate that remained after dialysis was removed by centrifugation.

Step 2. Acetone fractionation.

To the dialyzed solution, cold acetone was added to a final concentration of $30 \%$. After the precipitate was removed by centrifugation, the supernatant was brought to the final concentration of $70 \%$ with cold acetone. The precipitate was collected by centrifugation and suspended in one-fortieth volume of the culture supernatant of $10 \mathrm{~mm}$ $\mathrm{Ca}^{2}$ acetate- $1 \mathrm{~mm}$ Tris-maleate buffer (TMCa buffer), $\mathrm{pH}$ 6.4. This suspension was dialyzed against TMCa buffer, and then the residue after dialysis was removed by centrifugation.

Step 3. CM-Sepharose column chromatography.

The dialyzed solution obtained in Step 2 was concentrated to about half the original volume by ultrafiltration with a Diaflo YM5 membrane and put on a CMSepharose CL-6B column $(3.3 \times 42.5 \mathrm{~cm})$ equilibrated with TMCa buffer. The column was washed with TMCa buffer, and the enzyme was eluted with a linear gradient from 0 to $0.5 \mathrm{M} \mathrm{NaCl}$ in TMCa buffer.

Step 4. DEAE-Sepharose column chromatography.

The active fractions eluted from the CM-Sepharose column were combined and concentrated to about $30 \mathrm{ml}$ by ultrafiltration. After being dialyzed against TCa buffer, the concentrated solution was applied to a DEAESepharose CL-6B column $(2.6 \times 42.5 \mathrm{~cm})$ equilibrated with TCa buffer, and the enzyme was eluted with a linear gradient from 0 to $0.5 \mathrm{M} \mathrm{NaCl}$ in $\mathrm{TCa}$ buffer. The enzyme fractions were combined and dialyzed against TMCa buffer. The dialyzed solution was stored at $-20^{\circ} \mathrm{C}$ as the purified enzyme.

The neutral protease produced by B. subtilis 1A20pNP150 was purified by ammonium sulfate precipitation and CM-Sepharose column chromatography. The conditions of the precipitation and the chromatography were as described above.

Protease activity. The activity of the protease was assayed by casein hydrolysis using the method of Hagihara et $a$. $^{7)}$ (1958) modified by us. The enzyme solution was diluted with an equal volume of $20 \mathrm{~mm}$ Tris- $\mathrm{HCl}(\mathrm{pH} 7.5)$. After $0.5 \mathrm{ml}$ of $0.6 \%$ casein solution in $50 \mathrm{~mm}$ phosphate buffer was preincubated at $30^{\circ} \mathrm{C}$, the enzyme reaction was started by the addition of $0.1 \mathrm{ml}$ of the diluted enzyme solution; the mixture was incubated at $30^{\circ} \mathrm{C}$ for $20 \mathrm{~min}$. The reaction was stopped by the addition of $500 \mu 1$ of a mixture of $0.1 \mathrm{M}$ trichloroacetic acid, $0.22 \mathrm{M}$ sodium acetate, and $0.33 \mathrm{M}$ acetic acid. The absorbance at $275 \mathrm{~nm}$ of the acid-soluble supernatant was measured after centrifugation. The protease activity remaining in the presence of diisopropyl fluorophosphate (DFP) was taken to be that of neutral protease, while the protease activity not blocked by EDTA was that of alkaline protease. One unit of proteolytic activity was defined as the amount of enzyme yielding an increase of 0.01 in absorbance at $275 \mathrm{~nm}$ per $\min$ at $30^{\circ} \mathrm{C}$.

Protein assay. Protein concentrations were measured by the method of Lowry et al. ${ }^{8)}$ with bovine serum albumin as the standard.

SDS-polyacrylamide gel electrophoresis. SDS-polyacrylamide gel electrophoresis was done as described by Laemmli ${ }^{9}$ ) using a $3 \%$ polyacrylamide gel as the stack- 
ing gel and a $12 \%$ gel as the separation gel. A sample was mixed with an equal volume of the sample buffer and heated for $2 \mathrm{~min}$ at $100^{\circ} \mathrm{C}$, and then applied to the gel after rapid cooling. The sample buffer contained $0.25 \mathrm{M}$ Tris$\mathrm{HCl}, 4 \% \mathrm{SDS}, 20 \%$ glycerin, and a small amount of bromophenol blue (BPB), $\mathrm{pH}$ 6.8. Bovine serum albumin $(66 \mathrm{~K})$, egg albumin $(45 \mathrm{~K})$, tripsinogen $(24 \mathrm{~K})$, and $\beta$ lactoglobulin $(18.4 \mathrm{~K})$ were the molecular weight references.

Double immunodiffusion test. Double immunodiffusion was done using the method of Ouchterlony and Nilsson ${ }^{10)}$ (1973). Antiserum against B. subtilis IAM1212 neutral protease was generously supplied by Dr. K. Yamane. Antiserum against $B$. amyloliquefaciens $\mathrm{F}$ neutral protease was obtained from an immunized rabbit using a homogeneous preparation of the neutral protease purified in our laboratory after mixture with complete Freund's adjuvant (Difco).

Determination of $N$-terminal amino acid sequence. The purified preparation of the neutral proteases was mixed with an equal volume of the sample buffer without BPB (see SDS-polyacrylamide gel electrophoresis), heated for $2 \mathrm{~min}$ at $100^{\circ} \mathrm{C}$, and dialyzed against distilled water. The denatured sample was subjected to Edman degradation in an Applied Biosystems 470A Peptide Sequencer. PTHamino acids were identified using a HPLC (SpectraPhysics).

Chemicals. DFP was purchased from Fluka AG. CMSepharose CL-6B and DEAE-Sepharose CL-6B were purchased from Pharmacia. Other chemicals were of reagent grade and were used without further purification.

\section{RESULTS}

\section{Purification of the neutral proteases}

Recovery of neutral protease from B. amyloliquefaciens was $14.4 \%$ (Table I). The purified enzyme had the specific activity of $4 \sim 5 \times 10^{3}$ units/mg protein by our assay method. (This specific activity corresponds to $8 \sim 10 \times 10^{3}$ units/mg protein by the method of Fujisawa and Tsuru. ${ }^{11)}$

To reduce proteolytic modification by alkaline protease, culture was stopped in the early stationary phase when the amount of alkaline protease was still small. Moreover, contaminating alkaline proteases was removed by CM-Sepharose and DEAE-Sepharose column chromatography. Neutral and alkaline proteases were eluted from the CM-Sepharose column at concentrations of about $0.1 \mathrm{M}$ and $0.15 \mathrm{M} \mathrm{NaCl}$, respectively (Fig. 1). Alkaline

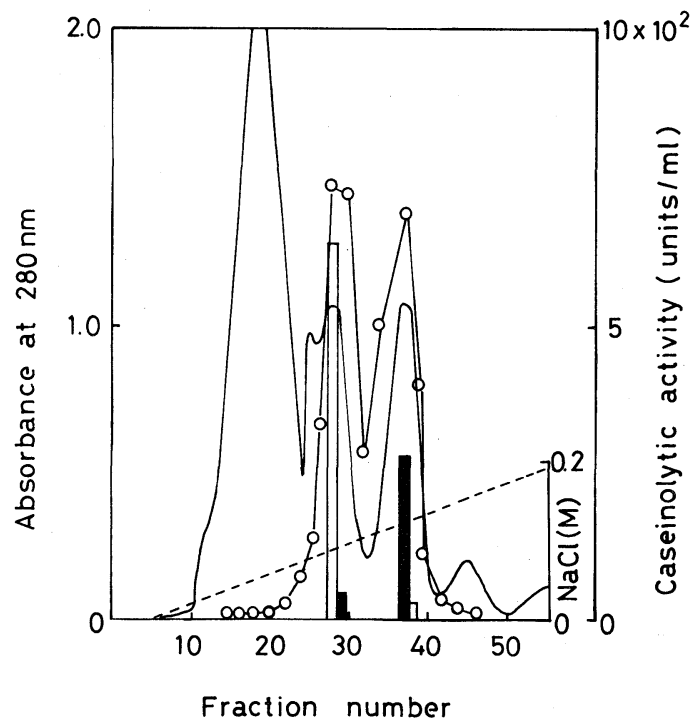

FIG. 1. Elution Pattern of Neutral Protease of Bacillus amyloliquefaciens from a CM-Sepharose Column.

Elution was with a linear gradient of from 0 to $0.5 \mathrm{M} \mathrm{NaCl}$ in $10 \mathrm{~mm} \mathrm{Ca}^{2+}$ acetate- $1 \mathrm{~mm}$ Tris-maleate buffer, $\mathrm{pH} 6.4$, at a flow rate of $60 \mathrm{ml} / \mathrm{hr}$. Each fraction was $20 \mathrm{ml}$.

- , absorbance at $280 \mathrm{~nm} ; \bigcirc-\bigcirc$, caseinolytic activity; $\square$, neutral protease activity; $\square$, alkaline protease activity; ------, $\mathrm{NaCl}$.

Table I. Purification of Neutral Protease of B.amyloliquefaciens $\mathrm{F}$

\begin{tabular}{lccccc}
\hline \multicolumn{1}{c}{ Step } & $\begin{array}{c}\text { Total } \\
\text { Volume } \\
(\mathrm{ml})\end{array}$ & $\begin{array}{c}\text { Total } \\
\text { activity } \\
\left(\times 10^{-3} \text { units }\right)\end{array}$ & $\begin{array}{c}\text { Total } \\
\text { protein } \\
(\mathrm{mg})\end{array}$ & $\begin{array}{c}\text { Specific } \\
\text { activity } \\
(\text { units/mg })\end{array}$ & $\begin{array}{c}\text { Recovery } \\
(\%)\end{array}$ \\
\hline Culture supernatant & 4420 & 1400 & 31800 & 44 & 100 \\
AmSO $_{4}$ precipitate & 1177 & 1040 & 4140 & 252 & 74.7 \\
Acetone precipitate & 120 & 662 & 756 & 876 & 47.4 \\
CM-Sepharose & 100 & 424 & 161 & 2630 & 30.3 \\
DEAE-Sepharose & 35 & 201 & 49 & 4100 & 14.4 \\
\hline
\end{tabular}


protease was not adsorbed by DEAESepharose, but the neutral protease was, so that neutral and alkaline proteases were completely separated in this step (see Fig. 2. Alkaline protease activity was not ditected in this chromatography.).

Enzyme recovery from $B$. subtilis NP58 was almost the same as for $B$. amyloliquefaciens (Table II).

Production of the neutral protease by the transformant (B. subtilis 1A20-pNP150) reached $1.5 \times 10^{3}$ units $/ \mathrm{ml}$ (about $300 \mathrm{mg} /$ liter)

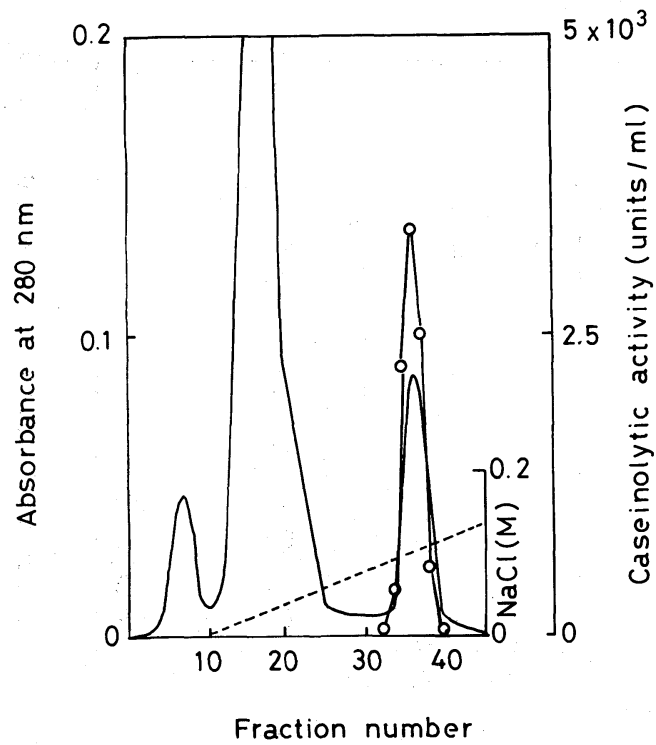

Fig. 2. Elution Pattern of Neutral Protease of Bacillus amyloliquefaciens from a DEAE-Sepharose Column.

Elution was with a linear gradient of from 0 to $0.5 \mathrm{M} \mathrm{NaCl}$ in $10 \mathrm{~mm} \mathrm{Ca}^{2+}$ acetate-10 mm Tris- $\mathrm{HCl}$ buffer, $\mathrm{pH} 7.2$, at a flow rate of $30 \mathrm{ml} / \mathrm{hr}$. Each fraction was $10 \mathrm{ml}$.

- , absorbance at $280 \mathrm{~nm} ; \bigcirc-\mathrm{O}$, caseinolytic activity; ,$----- \mathrm{NaCl}$. in the BY medium. Because of this high productivity, the transformant enzyme could be purified from the culture supernatant by only two steps; recovery was about the same as for B. amyloliquefaciens and B. subtilis (Table II).

Inhibition of the purified neutral proteases by EDTA and DFP

Findings on inhibition of the purified enzymes by EDTA and DFP are in Table III. The caseinolytic activity of the proteases of $B$. amyloliquefaciens and B. subtilis was not completely inactivated by $4.2 \mathrm{~mm}$ EDTA. Residual activity in the presence of EDTA was not that of alkaline protease, because $\mathrm{Ca}^{2+}$ ion was not entirely removed by EDTA under the assay conditions described in Table III $\mathrm{CCa}^{2+}$, $0.85 \mathrm{~mm}$; EDTA, $4.2 \mathrm{~mm}$ during the enzyme reaction). These purified enzymes were not inhibited by incubation in the presence of $2 \mathrm{~mm}$ DFP. The enzyme activity of the transformant was inhibited by EDTA to the same level as the $B$. amyloliquefaciens enzyme, and was not inactivated by DFP, as for both B. amyloliquefaciens and B. subtilis enzymes. These results indicate that all three of these enzymes

TABle II. SPecific Activity AND Yield OF Purified Neutral Proteases

\begin{tabular}{lcc}
\hline \multicolumn{1}{c}{ Enzyme source } & $\begin{array}{c}\text { Specific } \\
\text { activity } \\
\text { (units/mg) }\end{array}$ & $\begin{array}{c}\text { Yield } \\
(\%)\end{array}$ \\
\hline B. amyloliquefaciens & 4100 & 14.4 \\
B. subtilis NP58 & 2200 & 12.7 \\
B. subtilis 1A20-pNP150 & 5170 & 15.4 \\
\hline
\end{tabular}

Table III. EfFect of EDTA and DFP on Purified EnZymes

Enzymes were incubated in $5 \mathrm{mM} \mathrm{CaCl}_{2}-10 \mathrm{~mm}$ Tris- $\mathrm{HCl}$ buffer, $\mathrm{pH} 7.2$, containing $25 \mathrm{~mm}$ EDTA or $2 \mathrm{~mm}$ DFP for $30 \mathrm{~min}$ at $0^{\circ} \mathrm{C}$. Then, the caseinolytic activity was measured.

\begin{tabular}{lccccc}
\hline & $\begin{array}{c}\text { Concn during } \\
\text { reaction } \\
(\mathrm{mM})\end{array}$ & $\begin{array}{c}\text { B. amylo- } \\
\text { Reaquefaciens } \mathrm{F}\end{array}$ & $\begin{array}{c}\text { B. sub. } \\
\text { NP58 }\end{array}$ & $\begin{array}{c}\text { B. sub. 1A20- } \\
\mathrm{pNP} 150\end{array}$ & $\begin{array}{c}\text { Subtilisin } \\
\text { BPN' }^{\prime}\end{array}$ \\
\cline { 3 - 6 } & - & 100 & 100 & 100 & 100 \\
None & 4.2 & 8.4 & 2.0 & 8.8 & 103 \\
EDTA & 0.33 & 95.0 & 100 & 103 & 9.3 \\
DFP & & & & & \\
\hline
\end{tabular}




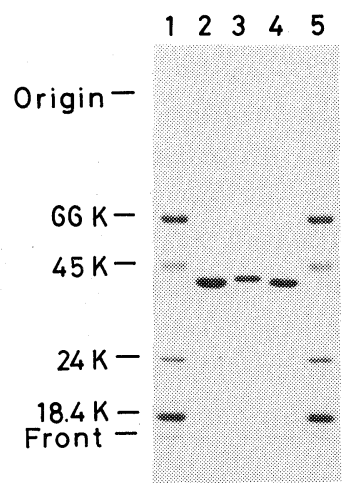

FIG. 3. SDS-polyacrylamide Gel Electrophoresis of Purified Neutral Protease from $B$. amyloliquefaciens F, $B$. subtilis NP58, and B. subtilis 1A20-pNP150.

The enzymes were denatured with the sample buffer (see Materials AND Methods) at $100^{\circ} \mathrm{C}$ for $2 \mathrm{~min}$. Electrophoresis was done on a $12 \%$ gel by the method of Laemmli, and protein was stained with Coomassie brilliant blue.

Lanes 1 and 5, molecular marker; 2, B. amyloliquefaciens $\mathrm{F}$ $(7.3 \mu \mathrm{g}) ; 3$, B. subtilis NP58 $(5.8 \mu \mathrm{g}) ; 4$, B. subtilis $1 \mathrm{~A} 20$ pNP150 $(7.0 \mu \mathrm{g})$.

are metalloproteases (that is, neutral proteases), and that alkaline protease was not contaminating these enzyme preparations.

\section{Mobility of neutral proteases in SDS- polyacrylamide gel}

We compared the mobility in SDSpolyacrylamide gel of the purified neutral proteases from B. amyloliquefaciens, B. subtilis, and the transformant. The protease of $B$. subtilis migrated slightly slower than that of $B$. amyloliquefaciens. This suggested that the $B$. subtilis NP58 enzyme probably has a slightly larger molecular weight or more positive charge than that from B. amyloliquefaciens. The mobility of the transformant enzyme was the same as that of $B$. amyloliquefaciens (Fig. 3).

\section{Immunological cross-reactivity of the neutral proteases}

We tested the immunological crossreactivity with their antibodies of the proteases from B. amyloliquefaciens, B. subtilis, and the transformant by double immunodiffusion. The antiserum against the $B$. amyloliquefaciens en-

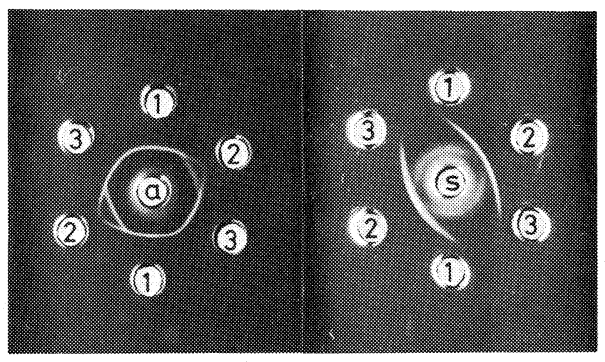

( A )

( B )

FIG. 4. Double Immunodiffusion Test of Purified Neutral Proteases from B. amyloliquefaciens F, B. subtilis NP58, and B. subtilis 1A20-pNP150.

Center well a, antiserum against neutral protease from $B$. amyloliquefaciens $\mathrm{F}$; $\mathrm{s}$, antiserum against neutral protease from B. subtilis IAM1212. Well 1, purified enzyme $(7.3 \mu \mathrm{g})$ from $B$. amyloliquefaciens $\mathrm{F}$; 2 , purified enzyme $(5.8 \mu \mathrm{g})$ from $B$. subtilis NP58; 3, purified enzyme $(5.6 \mu \mathrm{g})$ from $B$. subtilis 1A20-pNP150.

zyme formed a precipitin line with this enzyme, which line partially fused with that for the $B$. subtilis enzyme (Fig. 4A). When antiserum against $B$. subtilis IAM1212 neutral protease was used, the B. subtilis NP58 enzyme formed a very clear precipitin line, whereas the $B$. amyloliquefaciens enzyme formed vague, broad lines (Fig. 4B). These results indicate that the $B$. amyloliquefaciens enzyme has antigenicity in common with that of $B$. subtilis, but that those two enzymes are immunologically distinguishable. The precipitin line of the transformant enzyme completely fused with that of the $B$. amyloliquefaciens and partially with the B. subtilis enzymes (Fig. 4A). This result meant that the transformant enzyme was immunologically identical with the $B$. amyloliquefaciens enzyme. These electrophoretical and immunological results suggest that the transformant neutral protease is derived from the gene in B. amyloliquefaciens specifying this enzyme.

\section{$N$-terminal amino acid sequence of the proteases}

To identify the inserted gene specifying neutral protease, we determined the $\mathrm{N}$ terminal amino acid sequences of the enzymes of B. amyloliquefaciens, B. subtilis, and the transformant. The sequence for the $B$. amylo- 


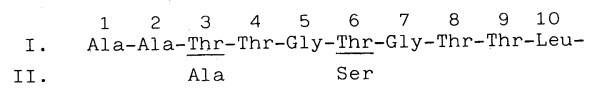

$\begin{array}{llllllllll}11 & 12 & 13 & 14 & 15 & 16 & 17 & 18 & 19 & 20\end{array}$ Lys-Gly-Lys-Thr-Val-Ser-Leu-Asn-Ile-SerAla Pro

Fig. 5. N-Terminal Amino Acid Sequences of Neutral Proteases.

In line I, amino acid sequences of the enzymes from $B$. amyloliquefacients $\mathrm{F}$ and the transformant are shown. In line II, the amino acid sequence of the enzyme from $B$. subtilis is given: only residues different from line I are shown.

liquefaciens protease (Fig. 5) coincided with the sequence for $B$. subtilis NRRLB3411 neutral protease reported by Levy et al. ${ }^{2)}$ When we compared the sequence for the B. subtilis NP58 enzyme with that for the $B$. amyloliquefaciens, there were 4 substitutions in the 20 amino acid residues at the $\mathrm{N}$-terminal (Thr-Ala at the $3 \mathrm{rd}$ position, Thr-Ser at the 6th, Lys-Ala at the 13th, and Ser-Pro at the 16th) from the Nterminus (Fig. 6; these positions are underlined.). This sequence for the transformant enzyme was the same as for B. amyloliquefaciens. These results suggest that the transformant neutral protease is specified by the $B$. amyloliquefaciens gene.

\section{DISCUSSION}

The neutral proteases of $B$. subtilis and related species have been purified and studied, ${ }^{2,11 \sim 14)}$ but their immunological properties and primary structures are still unknown. To identify the origin of an inserted gene, we purified neutral proteases from $B$. amyloliquefaciens F (the DNA donor strain), B. subtilis NP58 (a derivative strain of $B$. subtilis M6160), and the transformant, and studied their immunological properties and primary structures. The productivity of neutral proteases by the hosts, B. subtilis 1A289 and $1 \mathrm{~A} 20$, was very low, so we used $B$. subtilis NP58 for enzyme purification instead, because the protease of NP58 is immunologically identical with those of the hosts (un- published observation) and immunologically indistinguishable from the B. subtilis M6160 and IAM1212 enzymes. ${ }^{3)}$

The neutral proteases from B. amyloliquefaciens and B. subtilis NP58 were rather unstable. Production was increased by using culture medium designed for industrial production (see Materials AND Methods), solving this problem. The proteases produced by B. amyloliquefaciens F and B. subtilis NP58 then reached $3 \times 10^{3}$ units $/ \mathrm{ml}$ (about $600 \mathrm{mg}$ / liter) and $7.5 \times 10^{2}$ units $/ \mathrm{ml}$ (about $300 \mathrm{mg} /$ liter), respectively. However, during their purification, acetone fractionation was needed to remove residual dextrin in the culture medium.

The transformant, B. subtilis 1A20-pNP150, in BY medium produced 50 -fold more neutral protease than $B$. amyloliquefaciens $\mathrm{F}$, and 1,200-fold more than B. subtilis 1A20. This protease in the culture supernatant of the transformant was immunologically identical with the B. amyloliquefaciens enzyme. The enzyme protein was major component of the ammonium sulfate precipitate, so that purification required only two steps; recovery of the purified enzyme was almost the same as for $B$. amyloliquefaciens and $B$. subtilis enzyme, in spite of the higher productivity. This low recovery was probably caused by a decrease in activity during ammonium sulfate precipitation. Autodegradation of the neutral protease may occur because of its high concentration and the shortage of other contaminating proteins, which might work as protecting agents from autodegradation.

B. amyloliquefaciens neutral protease had specific activity $(4,000 \sim 5,000$ units/mg protein) like that of the transformant enzyme (Table II; some deviation in specific activity was observed between different lots of the purified enzyme). However, the specific activity of the B. subtilis NP58 enzyme did not exceed 2,500 units/mg protein. As this enzyme was more unstable than that of B. amyloliquefaciens, rapid purification was required to prepare almost homogeneous enzyme. Therefore, we do not know if the NP58 neutral protease was partially denatured during purifi- 
cation, or if it has only about half of the specific activity of the $B$. amyloliquefaciens enzyme from the start.

Here, we found electrophoretical and immunological differences between $B$. amyloliquefaciens and B. subtilis neutral proteases. Moreover, determination of the $\mathrm{N}$-terminal amino acid sequence of the two neutral proteases revealed that the partial sequence reported by Levy et al. ${ }^{2)}$ was not of B. subtilis, but of B. amyloliquefaciens. To our knowledge, this work gives the first amino acid sequence for $B$. subtilis neutral protease. The $20 \%$ difference in the $\mathrm{N}$-terminal sequence of 20 residues between $B$. amyloliquefaciens and B. subtilis neutral proteases suggests that the genus Bacillus produces at least two very similar but not identical neutral proteases. That the $\mathrm{N}$ terminal amino acid sequence of the B. amyloliquefaciens neutral protease is the same as that of the protease produced by B. subtilis carrying the plasmid pNP150 clearly indicates that the neutral protease gene of $B$. amyloliquefaciens is inserted in $B$. subtilis.

Acknowledgments. We wish to thank H. Saito, T. Beppu, K. Yamane, and T. Komano for their invaluable suggestions and encouragement. We also wish to thank D. Tsuru for his kind advice on the purification of the neutral proteases.

This work was done as part of the national project,
"Research and Development Project of basic Technologies for Future Industries" supported by the Ministry of International Trade and Industry.

\section{REFERENCES}

1) M. Honjo, K. Manabe, H. Shimada, I. Mita, A. Nakayama and Y. Furutani, J. Biotechnol., 1, 265 (1984).

2) P. L. Levy, M. K. Pangburn, Y. Burstein, L. H. Ericsson, H. Neurath and K. A. Walsh, Proc. Natl. Acad. Sci. U.S.A., 72, 4341 (1975).

3) H. Uehara, Y. Yoneda, K. Yamane and B. Maruo, $J$. Bacteriol., 119, 82 (1974).

4) S. Chang and S. N. Cohen, Mol. Gen. Genet., 168, 111 (1979).

5) H. Saito, M. Kohiyama and Y. Ikeda, J. Gen. Appl. Microbiol., 7, 243 (1961).

6) K. Kadowaki, J. Hosoda and B. Maruo, Biochim. Biophys. Acta, 103, 311 (1965).

7) B. Hagihara, H. Matsubara, M. Nakai and K. Okunuki, J. Biochem., 45, 185 (1958).

8) O. H. Lowry, N. J. Rosebrough, A. L. Farr and R. T. Randall, J. Biol. Chem., 193, 265 (1951).

9) U. K. Laemmli, Nature, 227, 680 (1970).

10) Ö. Ouchterlony and L. A. Nilsson, "Handbook of Experimental Immunology," ed. by P. M. Weir, Blackwell, Oxford, 1973, p. 1.

11) K. Fujisawa and D. Tsuru, Int. J. Peptide Protein Res., 9, 18 (1977).

12) D. Tsuru, T. Yamamoto and J. Fukumoto, Agric. Biol. Chem., 30, 651 (1966).

13) J. D. McConn, D. Tsuru and K. Yasunobu, J. Biol. Chem., 239, 3706 (1964).

14) L. Keay and B. S. Wildi, Biotechnol. Bioengi., 12, 179 (1970). 